\title{
Peer-reviewed abstracts from the 2013 Student Poster Contest
}

\author{
Minerals and Metallurgical Processing Division \\ Society for Mining, Metallurgy, and Exploration, Inc. \\ February 27, 2013, Denver, CO
}

\author{
Foreword by Emily Sarver \\ Assistant professor, Mining and Minerals Engineering, Virginia Tech, Blacksburg, VA
}

During the 2013 SME Annual Meeting and Exhibit in Denver, CO, the Mineral Processing Division hosted its fourth Student Poster Contest. In total, there were 14 entries between the undergraduate and graduate divisions, representing the following institutions: the University of Utah, Michigan Technological University, the Colorado School of Mines, Columbia University, the South Dakota School of Mines and the University of Kentucky. All students participated in an open poster session and also an oral presentation session, where they delivered short summaries of their research. Given the range of exciting research topics presented and excellent quality of all entries, this year's contest was a huge success. Indeed, the judges had a difficult time narrowing down the field to finally name winners, who were announced during the MPD Luncheon on February 27.

In the undergraduate division, Michigan Tech's Katrina Swanson was awarded the first place prize for her poster, "Bed effects on iron ore reduction in the Midrex ITmk3ß process." Paul Hagadone, also of Michigan Tech, won second place for his poster, "Effects of scrubbing column shell geometry on carbon dioxide removal efficiency." And the University of Utah team of Kari Knott and Travis Willhard took third place for their poster, "3D particle shape and size of lunar simulants."

In the graduate division, first and second place prizes were awarded to Brett Spigarelli and Howard Haselhuhn, respectively, both of Michigan Tech, and third place went to Caelen Anderson, of the Colorado School of Mines. These awards are particularly noteworthy considering that the same three students were also the winners of the 2012 MPD Student Poster Contest. Extended abstracts describing the work of these up-andcoming researchers are included in this issue of Minerals \& Metallurgical Processing.

The 2013 contest was co-organized by Jon Kellar (department chair and professor, Materials and Metallurgical Engineering, South Dakota School of Mines) and Courtney Young (department head and professor, Metallurgical \& Materials Engineering, Montana Tech). The contest was judged by Emily Sarver (assistant professor, Mining and Minerals Engineering, Virginia Tech), Lisa Schlink (senior process engineer, FreeportMcMoran Copper and Gold, Inc.), Jacob Hohn (senior process development engineer, RSR Technologies, Inc.) and Mark Jorgensen (subject matter expert, Mining and Minerals, CH2MHill). M\&MP sincerely thanks these individuals for their efforts in producing this special issue.

Special thanks are extended to all sponsors of the 2013 MPD Student Poster Contest, and also to all student participants. Please watch for upcoming details on the 2014 Contest. We look forward to seeing you in Salt Lake City!

The Mineral and Metallurgical Processing Division of SME was able to sponsor this contest thanks to the generous support of the companies that sponsored the MPD 2013-2014 calendar.

$\begin{array}{ll}\text { - } & \text { ABB } \\ \text { - } & \text { BASF } \\ \text { - } & \text { Cardero } \\ \text { - } & \text { Cytec } \\ \text { - } & \text { Eriez } \\ & \text { FLSmidth }\end{array}$

- Hazen Research

- Kappes, Cassiday \& Associates

- $\quad$ M3 Engineering

- Polysius Corp

- Tetra Tech

- Sepor 